\title{
19. NEOGENE PALYNOLOGY OF HOLES 794A, 795A, AND 797B IN THE SEA OF JAPAN: STRATIGRAPHIC AND PALEOENVIRONMENTAL IMPLICATIONS OF THE PRELIMINARY RESULTS ${ }^{1}$
}

\author{
Linda E. Heusser ${ }^{2}$
}

\begin{abstract}
This initial survey of pollen from 192 samples from Hole 794A, supplemented by 189 samples from Hole 795 and 797B, suggests that marine pollen assemblages from the southwestern Sea of Japan provide a consistent Neogene pollen stratigraphy and a solid basis for regional paleoenvironmental reconstructions.

Late Miocene vegetation inferred from these pollen data, a mix of conifer and broad-leaf elements with now-extinct Tertiary types well represented, appears similar to Aniai-type floras of Japan. During the late Miocene through early Pliocene, as Tertiary types declined, conifers (including the Sequoia/Cryptomeria group) became more prominent than broad-leaf elements, and herbs played an increasing role in the vegetation.

Middle Pliocene pollen assemblages imply significant changes in forest composition. In a 500,000-yr interval centered at $\sim 4$ m.y., Tertiary and warm-temperate deciduous types re-expanded and were comparable to or greater than middle-late Miocene levels. Temperate and cold-temperate conifers (Picea, Abies, Tsuga) were minimal. Subsequently, Tertiary and deciduous forest components (including Quercus) decreased, Picea, Tsuga, and Abies were again prominent, and herbs formed an increasingly larger part of the vegetation. Between $\sim 3$ m.y. and $\sim 2.5$ m.y., conifers, except for Cryptomeria types, were prominent, Quercus continued to decline, and other broad-leaf trees were minor. Over the last $2 \mathrm{Ma}$, the very large and frequent changes in forest composition inferred from pollen in the Sea of Japan correspond to forest dynamics inferred from changes in pollen and floral assemblages throughout Japan.

Given present vegetation/climate relationships, broad trends in Neogene climate inferred from these preliminary pollen data include decreasing temperatures, increasing seasonality in temperatures and precipitation, and increasing amplitude and frequency of climatic change. Two significant events, centered at $\sim 9$ m.y. and $\sim 4$ m.y., punctuate the gradual deterioration of the equable warm, humid subtropical/warm temperate late Miocene and early Pliocene climates. The first indication of cold-temperate conditions comparable to those of Pleistocene glacial intervals occurs $\sim 3 \mathrm{~m}$.y. Subsequently, regional climates oscillated rapidly between temperate and cold-temperate regimes that supported conifer and mixed broad-leaf forests; however, climatic extremes were apparently never great enough to displace warm-temperate and temperate forests from Honshu nor to produce arctic climates on the west coast of Japan.
\end{abstract}

\section{INTRODUCTION}

Analysis of plant microfossils in sediments deposited in the ocean may seem anomalous and even esoteric; however, pollen records obtained from deep-sea sediments provide useful and unique paleoclimatic and stratigraphic information: lengthy, continuous, chronostratigraphically controlled terrestrial paleoenvironmental records that are, by their nature, directly correlative with marine paleoenvironmental records derived from the same sediment samples. As these preliminary results of pollen analysis of Neogene sediments from Sites 794, 795, and 797 in the Sea of Japan suggest, marine pollen stratigraphy can provide a means of correlating marine sediments and of correlating marine and terrestrial stratigraphic and climatic records.

The source of pollen in the Ocean Drilling Program cores from the Sea of Japan is primarily the nearby vegetation of the Japanese archipelago (Heusser, 1989). The "natural" vegetation of Honshu and Hokkaido, Japan, can be divided into three major latitudinal/altitudinal forest groups: (1) warm-temperate evergreen broad-leaf, (2) temperate evergreen conifer and deciduous broad-leaf, and (3) subalpine (subboreal) conifer forests (Numata, 1974; Franklin et al., 1979; Igarashi, 1986). Mixing between elements of the cool-temperate and warm-temperate forests commonly makes distinction between these two forest zones tenuous, and the composition of all these groups varies in response to local climatic and edaphic factors. The compo-

\footnotetext{
'Pisciotto, K. A., Ingle, J. C., Jr., von Breymann, M. T., Barron, J., et al., 1992. Proc. ODP, Sci. Results, 127/128, Pt. 1: College Station, TX (Ocean Drilling Program).

${ }^{2}$ Lamont-Doherty Geological, Observatory of Columbia University, Palisades, NY 10964, U.S.A.
}

sition of natural lowland vegetation, which has been severely disturbed for more than $2000 \mathrm{yr}$, is essentially unknown.

Warm-temperate forests, which extend to $\sim 40^{\circ} \mathrm{N}$ on the Pacific coast, include Castanopsis (Chinquapin), Quercus (oak), and conifers such as Cryptomeria japonica (Japanese cedar) and Sciadopitys verticillata (Umbrella pine). Pinus thunbergii (pine) is essentially restricted to the coast and lowlands, whereas Tsuga sieboldii (hemlock), and/or Abies firma (fir) occur in higher elevations and in the northern parts of Honshu (Ohwi, 1984). Characteristic genera of cool-temperate forests, which form the primary part of the Japanese flora, include Quercus, Fagus (beech), Tsuga, and Abies, as well as Cryptomeria japonica. On Honshu, at elevations between $\sim 1000$ and $2400 \mathrm{~m}$, subalpine forests with Abies, Betula (birch), Picea (spruce), and Tsuga diversifolia develop (Franklin, 1979; Saito, 1979). Moors and alpine dwarf scrub with Betula ermanii and Pinus pumila occur above $\sim 2400 \mathrm{~m}$. In the north, on Hokkaido, broad-leaf deciduous forests merge with forests dominated by Picea jezoensis and Picea glehnii, Abies sachalinensis, B. ermanii, P. pumila, and Quercus mongolica. Coastal vegetation is characterized by extensive Sphagnum bogs, Alnus (alder) swamps, and mixed stands of conifers and hardwoods (Numata, 1974; Watanabe, 1979).

Distribution of Japanese vegetation is said to be primarily controlled by temperature because precipitation is relatively abundant ( 1000 to $>4000 \mathrm{~mm} / \mathrm{yr}$ ) throughout the archipelago. Like other mid-latitude oceanic climates, the climate of temperate Japan has a small annual mean temperature variation. Average January and July temperatures range from $5.3^{\circ} \mathrm{C}$ to $25^{\circ} \mathrm{C}$ in the warm-temperate zone, from $-1.0^{\circ} \mathrm{C}$ to $22.4^{\circ} \mathrm{C}$ in the cool-temperate zone, and from $-6.2^{\circ} \mathrm{C}$ to $17.8^{\circ} \mathrm{C}$ in the subarctic zone. Summer and winter isotherms curve northward on both sides of Honshu, reflecting the year-round 
influence of the warm, north-flowing Kuroshio current. A southern extension of the cold Oyashio current modifies temperatures on the Pacific coast of Hokkaido and Honshu to $\sim 35^{\circ} \mathrm{N}$ (Fukui, 1977).

Japanese climates are intimately related to North Pacific and northeast Asian marine and atmospheric climate processes. Differential heating of the Himalaya-Tibetan massif is a fundamental determinant of the monsoon climates of Japan. Spring and summer precipitation is primarily related to the southern monsoons, northward movement of the subtropical jet stream, and the intensity of the Ogasawara and North Pacific High. Development of winter monsoons reflects interactions of the Aleutian Low and the Siberian and Okhotsk High pressure systems (Fukui, 1977). The present distribution of the major vegetation zones of Japan reflects these climatic processes. The division between warm- and cool-temperate forests at $\sim 39^{\circ} \mathrm{N}$, for example, corresponds to the position of the atmospheric polar front and adjoins the marine front, the confluence of the two major North Pacific water masses (the subtropical and subarctic gyres) (Morley and Heusser, 1989).

Investigations of pollen and plant macrofossils in Neogene sediments suggest that the flora of Japan has been stable for the last $\sim 2$ m.y. There is no evidence of plant extinction or migration from the Asian continent since the middle Pleistocene and possibly since the Pliocene (Jimbo, 1964; Tai, 1973; Numata, 1974); however, the composition of vegetation in the Japanese island arc has changed repeatedly in response to Pliocene-Pleistocene climatic variations (Tai, 1973). Because plants now growing in Japan have been present in the archipelago throughout the late Neogene, recent vegetation/ climate relationships can serve as fairly reliable guides for the paleoclimatic interpretation of fossil pollen assemblages.
Paleoenvironmental reconstructions from pollen recovered from Japanese lakes and bogs are said to extend through the last $3 \mathrm{Ma}$ (Igarashi, 1976; Fuji, 1988; Igarashi et al., 1988; Tsukada, 1988; Miyoshi, 1989), and floral records of plant macrofossils and pollen extend through the Paleogene (Miki, 1941; Tai, 1973; Numata, 1974; Igarashi, 1976; Hase and Hatanaka, 1984; Igarashi et al., 1988). Prior to $\sim 30,000 \mathrm{yr}$, lengthy, continuous terrestrial records are rare, and the precise age of these older pollen records is not firmly established. The analysis of pollen in marine sediments deposited offshore, pioneered by Koroneva (1961) in the Sea of Japan, has recently directly correlated vegetation records of the Japanese archipelago with highresolution regional and global marine chronologies for the last 350,000 yr (Ishii et al., 1981; Morley et al., 1986; Heusser, 1989; Morley and Heusser, 1989).

This chapter presents the results of the preliminary pollen analyses of samples from Sites 794, 795, and 797 in the Sea of Japan in order to evaluate the stratigraphic and paleoenvironmental potential of pollen in Neogene sediments in the Sea of Japan.

\section{METHODS}

Three sites from Leg 127 were sampled for pollen (Fig. 1 and Table 1); Site 794 is on the northern edge of the Yamato Basin, $\sim 100 \mathrm{~km}$ west of northern Honshu. Site 797, located in the southwestern Yamato Basin, lies $\sim 300 \mathrm{~km}$ off the main island of Japan. The northernmost site in the northeastern Japan Basin, Site 795, is about equidistant between the west coast of Hokkaido and east coast of Sikhote-Alin, Siberia (Fig. 1 and Table 1). Samples for pollen analysis, $\sim 10 \mathrm{~cm}^{3}$ each, were taken from the upper $345 \mathrm{~m}$ from Hole $794 \mathrm{~A}$,

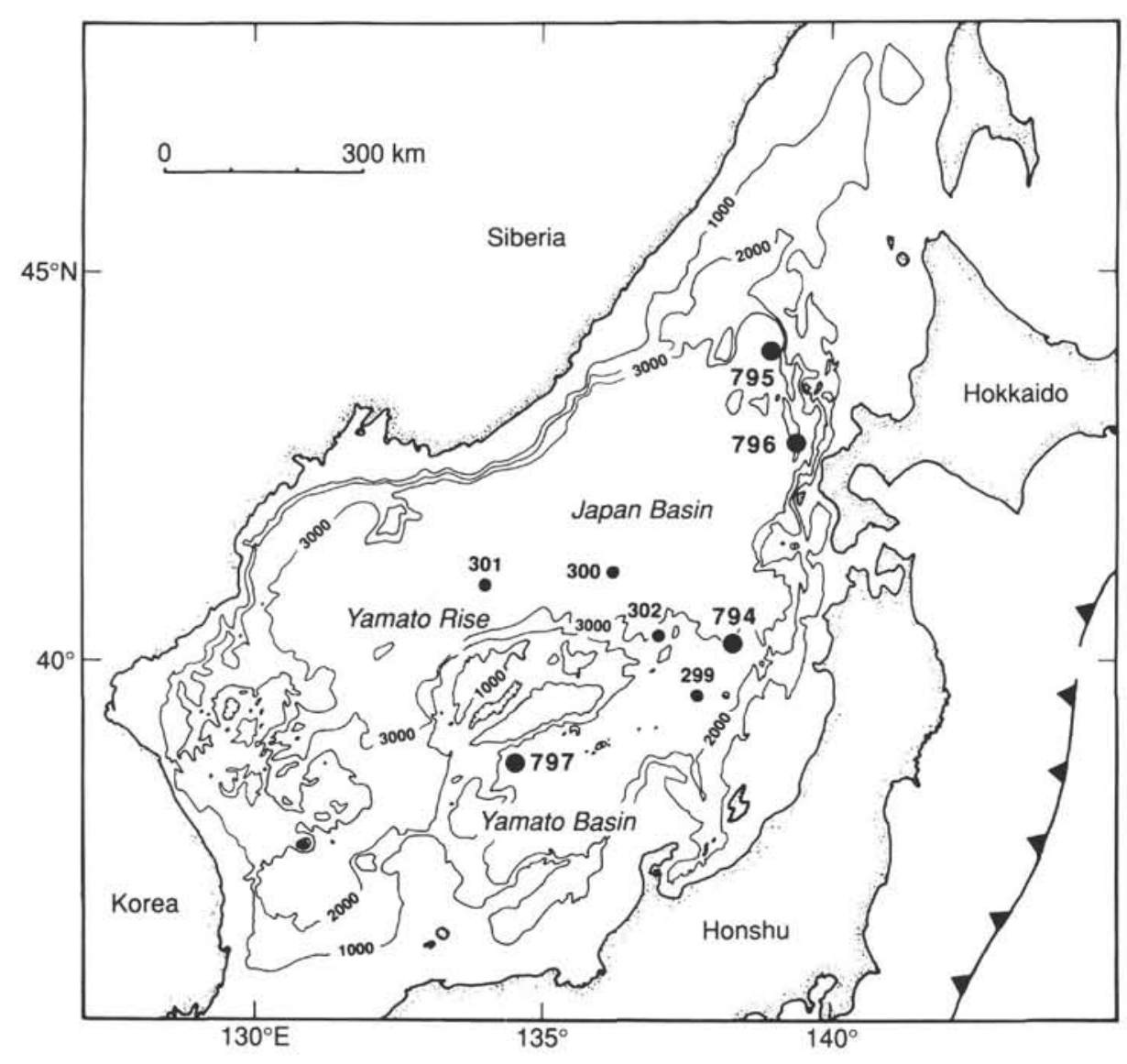

Figure 1. Location map of the Japan Basin showing Sites 794, 795, and 797 in the Sea of Japan. Bathymetry is in meters. 
Table 1. Location data for Sites 794, 795, and 797.

\begin{tabular}{lccc}
\hline Hole & Latitude (N) & Longitude (E) & Depth (mbsf) \\
\hline $794 \mathrm{~A}$ & $40^{\circ} 11.41^{\prime}$ & $138^{\circ} 13.86^{\prime}$ & 2821 \\
$795 \mathrm{~A}$ & $40^{\circ} 59.23^{\prime}$ & $138^{\circ} 58.03^{\prime}$ & 3311 \\
$797 \mathrm{~B}$ & $38^{\circ} 36.94^{\prime}$ & $134^{\circ} 32.16^{\prime}$ & 2862 \\
\hline
\end{tabular}

the upper $103 \mathrm{~m}$ from Hole $795 \mathrm{~A}$, and the upper $379 \mathrm{~m}$ from Hole 797B (Appendices A, B, and C). Preparation of these finegrained hemipelagic, diatomaceous, and terrigenous sediment samples, which ranged from $\sim 10$ to $15 \mathrm{~cm}^{3}$ from Hole $794 \mathrm{~A}$ and from $\sim 3$ to 10 gm dry weight from Hole $795 \mathrm{~A}$, followed techniques developed for isolating pollen from marine sediments (Heusser and Stock, 1984). The preparation of samples from Holes 794A and $795 \mathrm{~A}$ included the initial addition of a known quantity of a marker pollen to a measured quantity of sediment in order to calculate the pollen concentration (pollen/grams dry weight sediment $=$ gdws) and to serve as a reference for estimating pollen preservation/degradation. Our reference collections of modern Japanese pollen and spore taxa along with published morphological descriptions and keys (such as Ueno, 1951; Maeda, 1970; Miyoshi, 1984, 1986) were used in pollen and spore identification. Variable pollen preservation and the common occurrence of pyrite hindered some pollen identification. Because criteria used to distinguish subgenera of Quercus (Cyclobalanopsis and Lepidobalanus), Taxodiaceous (Cryptomeria, Sequoia, Metasequoia), and Cupressaceous (Chamaecyparis, Thuja, Juniperus) genera and to separate Pinus into subgroups were not consistently observed, the taxonomic classification of pollen was usually conservative. Pinus and Quercus are, therefore, all-inclusive groups. Cryptomeria was separated from other Taxodiaceae only when the distinguishing characteristics were clearly visible. Although some taxodiaceous pollen grains that could be identified as Sequoia/Metasequoia were present in sediments deposited before $\sim 3.45$ m.y., they were not segregated from Cryptomeria-type pollen in this preliminary survey. If the identification of papillate pollen (e.g., Cryptomeria) was ambiguous, the pollen grains were placed in the Taxodiaceae/Cupressaceae group. Botanical nomenclature follows Ohwi (1984).

Pollen and spores were analyzed from 192 samples from Site 794 (Appendix A), from 67 samples from Site 795 (Appendix B), and from 122 samples from Site 797 (Appendix C). Pollen percentages were calculated from the total pollen number of arboreal and non-arboreal pollen identified. In the time available for this initial survey of pollen in cores taken on ODP Legs 127 and 128, a minimum of 100 pollen grains per sample were counted (Appendix A). The pollen sum includes types such as Alnus, that are excluded from some basic pollen sums in Japanese terrestrial pollen diagrams to reduce local over-representation (Tsukada, 1988). If less than 100 pollen grains were identified, the sample was regarded as nonproductive and was not included in the pollen data in the Appendices. Percentages of spores such as Selaginella, Sphagnum, and members of the Polypodiaceae and Lycopodiaceae are calculated outside the basic pollen sum as the ratio of spores/spores plus pollen. Because of the preliminary nature of this study, pollen data were not divided into formal pollen zones.

\section{CHRONOSTRATIGRAPHY}

Age control (Table 2) for the sediments recovered from Holes 794A, $795 \mathrm{~A}$, and 797B derives from paleomagnetic measurements and siliceous and calcareous biostratigraphic datums (Tamaki, Pisciotto, Allan, et al., 1990). Identification of a Japanese marker tephra with an estimated age of $\sim 0.7-0.8 \mathrm{~m}$.y. (the Aso 4 ash) (R. Tada. pers. comm., 1991) and correlation between late Quaternary terrestrial and marine pollen data provide additional chronostratigraphic control
Table 2. Age-depth datums used to establish the preliminary age models for Sites 794, 795, and 797 .

\begin{tabular}{|c|c|c|c|c|c|c|}
\hline \multirow[b]{2}{*}{ Site } & \multirow{2}{*}{$\begin{array}{l}\text { Depth } \\
\text { (mbsf) }\end{array}$} & \multirow{2}{*}{$\begin{array}{l}\text { Age } \\
\text { (Ma) }\end{array}$} & \multicolumn{2}{|c|}{ Sedimentation rate } & \multirow{2}{*}{$\begin{array}{l}\text { Mean dry- } \\
\text { bulk density } \\
\left(\mathrm{g} / \mathrm{cm}^{2}\right)\end{array}$} & \multirow{2}{*}{$\begin{array}{c}\text { Accumulation } \\
\text { rate } \\
\left(\mathrm{g} / \mathrm{cm}^{2} 1000 \mathrm{yr}\right)\end{array}$} \\
\hline & & & $(\mathrm{m} / \mathrm{m} . \mathrm{y})$. & $(\mathrm{cm} / 1000 \mathrm{yr})$ & & \\
\hline \multirow[t]{17}{*}{794} & 0 & 0 & & & & \\
\hline & 25.5 & 0.73 & 35 & 3.5 & 0.92 & 3.22 \\
\hline & & & 33 & 3.3 & 1 & 3.3 \\
\hline & 34 & 0.98 & 30 & 3 & 102 & 3.06 \\
\hline & 55.5 & 1.66 & & & & \\
\hline & & & 25 & 2.5 & 1.02 & 2.56 \\
\hline & 75.4 & 2.47 & 33 & 3.3 & 0.89 & 2.94 \\
\hline & 92.4 & 2.99 & & & & \\
\hline & & & 39 & 3.9 & 0.87 & 3.38 \\
\hline & 100.3 & 3.4 & 29 & 2.9 & 0.89 & 2.59 \\
\hline & 148.4 & 4.77 & & & & \\
\hline & & & 42 & 4.2 & 0.83 & 3.47 \\
\hline & & 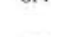 & 49 & 4.9 & 0.8 & 3.93 \\
\hline & 255.7 & 7.2 & & & & \\
\hline & & & 54 & 5.4 & 0.8 & 4.34 \\
\hline & & & 36 & 3.6 & 1.24 & 4.48 \\
\hline & 530.5 & 14.4 & & & & \\
\hline \multirow[t]{5}{*}{795} & 0 & 0 & & & & \\
\hline & & & 48 & 4.8 & 0.96 & 4.6 \\
\hline & & & 56 & 5.6 & 0.94 & 5.3 \\
\hline & 87 & 1.66 & & & & \\
\hline & 151.9 & 2.5 & 77 & 7.7 & 0.93 & 7.2 \\
\hline \multirow[t]{8}{*}{797} & 0 & 0 & & & & \\
\hline & & & 46 & 4.6 & 0.88 & 4.1 \\
\hline & 81.9 & 1.0 & 50 & 5 & 0.86 & 4.3 \\
\hline & 166.4 & 3.5 & & & & \\
\hline & 243.4 & 5.3 & 43 & 4.3 & 0.85 & 3.7 \\
\hline & & & 56 & 5.6 & 1.02 & 5.7 \\
\hline & 350 & 7.2 & & & 147 & 07 \\
\hline & 369.6 & 11.6 & . & .5 & 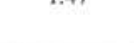 & .1 \\
\hline
\end{tabular}

(Heusser, 1990). Using sedimentation rates determined from these age models (Table 2), intervals between productive pollen samples range from 0.04 m.y. in Hole 794A to 2 m.y. in Hole 797B.

\section{RESULTS}

In $\sim 95 \%$ of the 381 samples processed, pollen was relatively abundant and generally well preserved. Pollen concentration ranged from $<100$ to $>100,000$ pollen grains/gdws. The concentration of pollen was exceptionally high in upper Quaternary sediment from Hole 794A and in a few Pleistocene samples from Hole 795A. Better pollen preservation was typically associated with abundant organic matter, including dark plant? fragments (possibly charcoal) and with pyrite. In samples in which pollen appeared highly corroded or in which pollen was rare (samples in which less than 100 pollen grains could be identified), undigested siliceous particles were commonly present. The relative abundance of other palynomorphs, such as dinoflagellate cysts, fungal spores, microforaminifers, and denticles, varied. Reworked Mesozoic or Paleogene pollen and spores were rare.

As seen in the summary of selected pollen statistics (Table 3), conifers (Pinus, Picea, and Cryptomeria) are numerically the most important pollen taxa in sediments from Sites 794, 795, and 797. Like 
Table 3. Summary of pollen statistics from Holes 794A, 795A, and 797B.

\begin{tabular}{lllclcc}
\hline Hole & Taxon & $\begin{array}{c}\text { Minimum } \\
(\%)\end{array}$ & $\begin{array}{c}\text { Maximum } \\
(\%)\end{array}$ & $\begin{array}{c}\text { Mean } \\
(\%)\end{array}$ & $\begin{array}{c}\text { Standard } \\
\text { deviation }\end{array}$ & $\begin{array}{c}\text { Standard } \\
\text { error }\end{array}$ \\
\hline 794A & Pinus & 0.03 & 0.7 & 0.29 & 0.11 & 0.009 \\
& Picea & 0.04 & 0.57 & 0.15 & 0.11 & 0.008 \\
& Cryptomeria & 0 & 0.72 & 0.06 & 0.09 & 0.007 \\
& Quercus & 0.01 & 0.29 & 0.1 & 0.05 & 0.003 \\
& Alnus & 0 & 0.2 & 0.02 & 0.02 & 0.002 \\
$795 \mathrm{~A}$ & & & & & & \\
& Pinus & 0.02 & 0.8 & 0.25 & 0.14 & 0.02 \\
& Picea & 0.02 & 0.85 & 0.38 & 0.22 & 0.03 \\
& Cryptomeria & 0 & 0.1 & 0.03 & 0.02 & 0.003 \\
& Quercus & 0 & 0.18 & 0.04 & 0.04 & 0.005 \\
& Alnus & 0 & 0.43 & 0.02 & 0.06 & 0.008 \\
& & & & & & \\
$797 \mathrm{~B}$ & Pinus & 0.03 & 0.59 & 0.29 & 0.13 & 0.014 \\
& Picea & 0 & 0.58 & 0.1 & 0.1 & 0.011 \\
& Cryptomeria & 0 & 0.59 & 0.06 & 0.12 & 0.012 \\
& Quercus & 0 & 0.36 & 0.13 & 0.07 & 0.008 \\
& Alnus & 0 & 0.11 & 0.02 & 0.04 & 0.004
\end{tabular}

these conifers, Quercus, the leading deciduous pollen type, and Alnus, the most abundant secondary taxon, display regional trends. Pinus, Picea, and Alnus decrease from north to south; the reverse is true of Cryptomeria and Quercus.

Variations in the most common diagnostic taxa in sediments from the Sea of Japan are shown in both the depth and time domain. To synthesize the pollen data, some taxa are combined into groups that can be interpreted as ecologic units. For example, in cool-temperate and boreal environments, such as the subalpine zone of central Japan or the central mountain ranges of Hokkaido, pollen of Picea, Abies, and Tsuga is more abundant that of Quercus, Fagus, and other deciduous types (Tsukada, 1988). Deciduous pollen types here include Fagus, Ulmus, Juglans, and Tilia. Betula and Alnus are secondary or pioneer species, and herbs (here composed of members of the Compositae, Chenopodiaceae, Gramineae, and Cyperaceae) generally reflect open environments. The Tertiary pollen group includes plants now extinct in Japan, such as Carya, Liquidambar, Nyssa, and Sequoia/Metasequoia.

\section{Hole 794A}

Over much of the pollen record from Hole 794A (Fig. 2), Pinus fluctuates between $10 \%$ and $50 \%$. Two major interruptions to this rather stable trend (at $\sim 125 \mathrm{~m}$ below seafloor (mbsf) and $\sim 75 \mathrm{mbsf}$ ) precede the high-amplitude oscillations that characterize the upper $\sim 25 \mathrm{~m}$ in Pinus and the Picea + Abies + Tsuga group. The latter rises from a basal low to a peak at $\sim 275 \mathrm{mbsf}$, declines at $\sim 175 \mathrm{mbsf}$, and then exhibits a resurgence centered at $\sim 150 \mathrm{mbsf}$. The lowest values in the boreal conifer record, which occur $\sim 125 \mathrm{mbsf}$, are followed by a gradual steplike rise, after which percentages of boreal conifers fluctuate between $5 \%$ and $65 \%$ in the upper $50 \mathrm{~m}$. Even higher amplitude oscillations are seen in the relative abundance of Cryptomeria, which ranges from $0 \%$ to $80 \%$ in the same upper $50-\mathrm{m}$ interval. In contrast, Cryptomeria percentages in the basal $300 \mathrm{~m}$ of the record generally remain low, increasing to $\sim 30 \%$ between 200 and 100 mbsf. High-amplitude changes, which characterize the lower $100 \mathrm{~m}$ of the Quercus profile, dampen between 200 and $100 \mathrm{mbsf}$, where the average representation of Quercus remains relatively stable. Percentages of Quercus begin a steady decrease at $\sim 100$ mbsf. An overall upward increase in the relative contribution of herbs to the pollen sum is characterized by high-amplitude fluctuations in the upper 75 mbsf. Similar high-frequency oscillations are seen in the pollen signatures of Betula + Alnus from the uppermost sediments from Hole 794A. The pattern of the Tertiary types and deciduous pollen types other than Quercus is distinctive - an overall upward decline marked by two robust peaks. In Tertiary pollen types, the first peak (between 350 and $300 \mathrm{mbsf}$ ) is more pronounced than the second, which is centered at $\sim 125$ mbsf (Fig. 2). Because sedimentation rates in the upper $\sim 400 \mathrm{~m}$ of Hole 794A do not change appreciably, pollen profiles plotted with age on the $y$ axis (Fig. 3) are similar to depth plots of the same taxonomic groups.

Except for samples from the last 1 million years, in which pollen/gdws increases by a factor of 10 , the concentrations of various pollen types in sediments from 794A (Fig. 4) show the same major variations seen in the pollen percentage diagrams: a late Miocene decline in deciduous and Tertiary types followed by a rise in boreal components, a reversal in these trends centered at $4 \mathrm{~m} . \mathrm{y}$., an extended interval of Pinus and Picea + Abies + Tsuga dominance ( 3- 2.5 m.y.) succeeded by increased Cryptomeria and herbs ( $2.5-2.0$ m.y.), and the distinctive high-frequency, high-amplitude fluctuations of all pollen types in the last $\sim 1$ million years. In the Pleistocene, total pollen and deciduous and boreal pollen concentrations increase.

\section{Hole 795A}

In pollen percentage diagrams from Hole 795A (Fig. 5), as seen in the summary of pollen statistics (Table 3 ), the Picea + Tsuga + Abies group is more important than in sediments from comparable depths at Site 794 (Figs. 2 and 3). Except for three samples, these conifers, along with Pinus and Cryptomeria, form $>80 \%$ of the pollen sum in each sample. Pollen of deciduous types other than Quercus is relatively unimportant and Tertiary types, if present at all, are rare. Percentages of pollen types illustrated in Figure 5 change frequently, the frequency of change varying in proportion to relative abundance. Except for the herbs, and possibly Alnus + Betula, both of which gradually increase toward the top of the diagram, there are no discernable patterns in the other pollen types. This may reflect the coarse sampling interval.

Although changes in sedimentation rates in the upper $120 \mathrm{~m}$ of Hole $795 \mathrm{~A}$ range from 48 to $77 \mathrm{~m} / \mathrm{m}$.y., pollen percentages plotted against age (Fig. 6) differ little from the depth plots (Fig. 5). This may be an artifact of sample aliasing. Recovery of pollen was low in sediment from Hole 795A ( 15 of the 67 samples processed were nonproductive, Appendix B), although the range of pollen concentration was the same (Fig. 7).

\section{Hole 797A}

Conifers also dominate the pollen record from Hole 797A (Fig. 8 and Table 3), with the Picea + Tsuga + Abies group contributing about equally with Pinus. From a basal high of $\sim 50 \%-60 \%$, Pinus and the Picea + Tsuga + Abies group decrease to $\sim 10 \%$ between $\sim 325$ and $\sim 300$ mbsf and then rise steadily to peak values at $\sim 125$ mbsf, after which conifer percentages are characterized by high-amplitude, highfrequency oscillations. In the basal $\sim 300 \mathrm{~m}$, Cryptomeria percentages show a broad low-amplitude increase centered at $\sim 200 \mathrm{mbsf}$ and a second, shorter, higher increase at $\sim 100 \mathrm{mbsf}$. Like other conifers, percentages of Cryptomeria fluctuate abruptly back and forth in the upper $100 \mathrm{~m}$, from a high of $60 \%$ to $<5 \%$. The Betula + Alnus and herb curves are quite similar, exhibiting almost identical patterns of low-amplitude change to the upper one-third of the pollen diagram, where amplitude and frequency of change increase. In contrast to this pattern and that of all the conifers, percentages of Quercus, Tertiary, and other deciduous types display an overall decrease from the basal high at $\sim 300$ mbsf.

When plotted to time (Fig. 9), trends in pollen percentage data from Hole 797A resemble those from the last $\sim 7$ m.y. in Hole 794A (Fig. 3). An overall decrease in Quercus, other deciduous types, and Tertiary pollen contrasts with the general rise seen in the other four pollen groups. The apparent absence of the distinctive 4-m.y. increase in Tertiary and deciduous pollen groups seen in pollen data from Hole 794A may reflect the low sampling resolution and lack of 

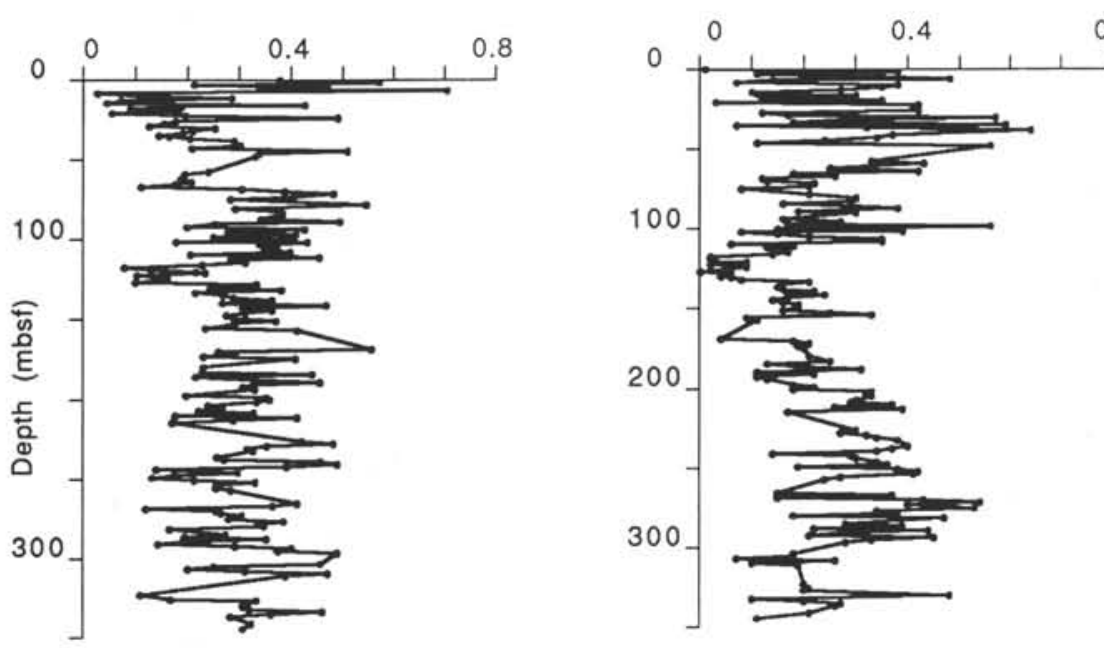

Quercus
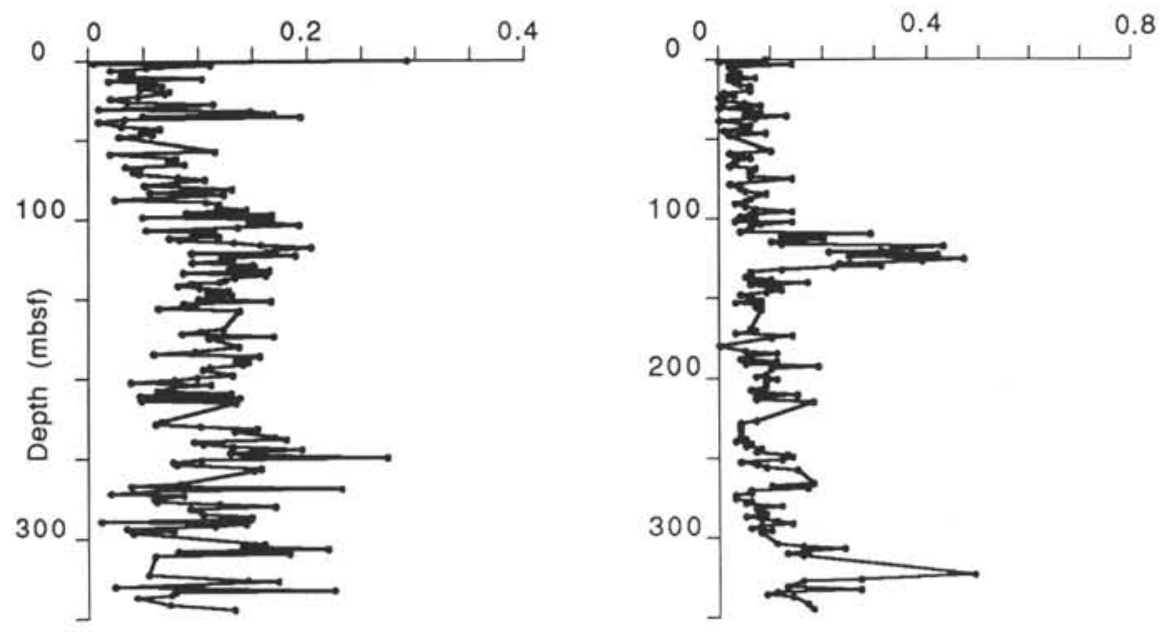

0

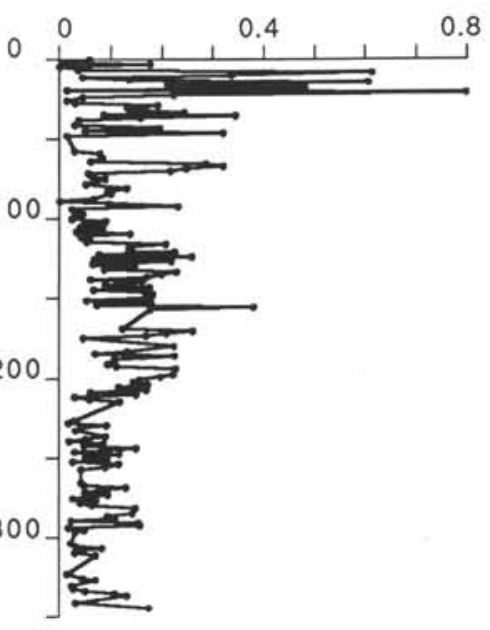

Betula + Alnus

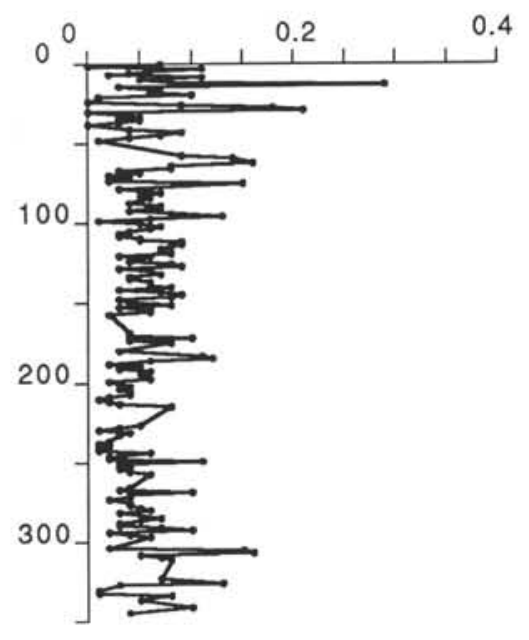

Herbs

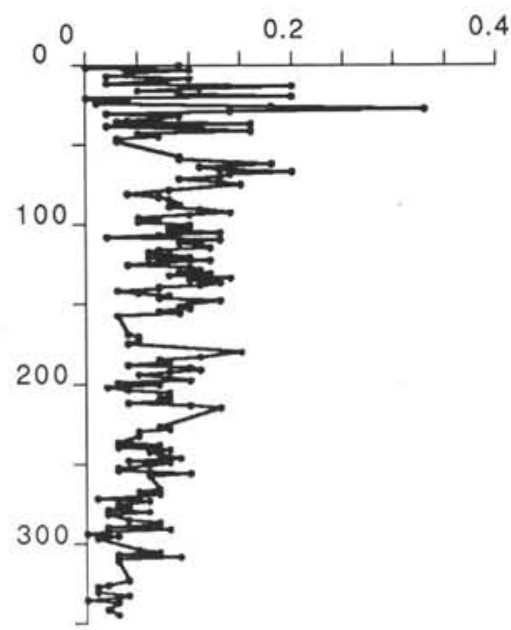

Tertiary types

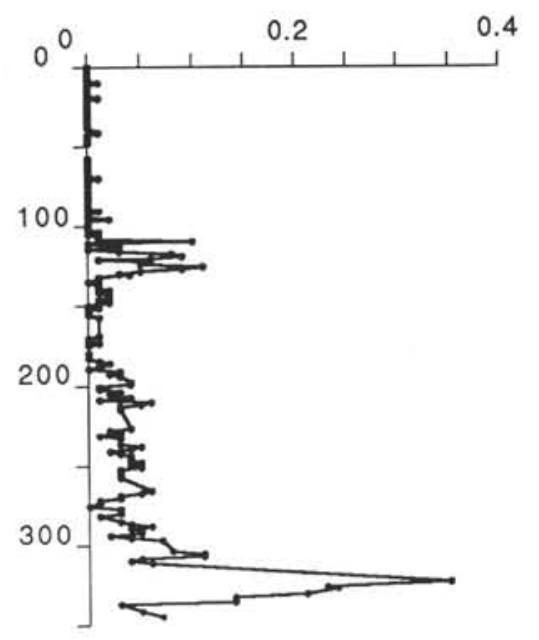

Figure 2. Percentages of selected pollen taxa from Hole 794A plotted to depth. 

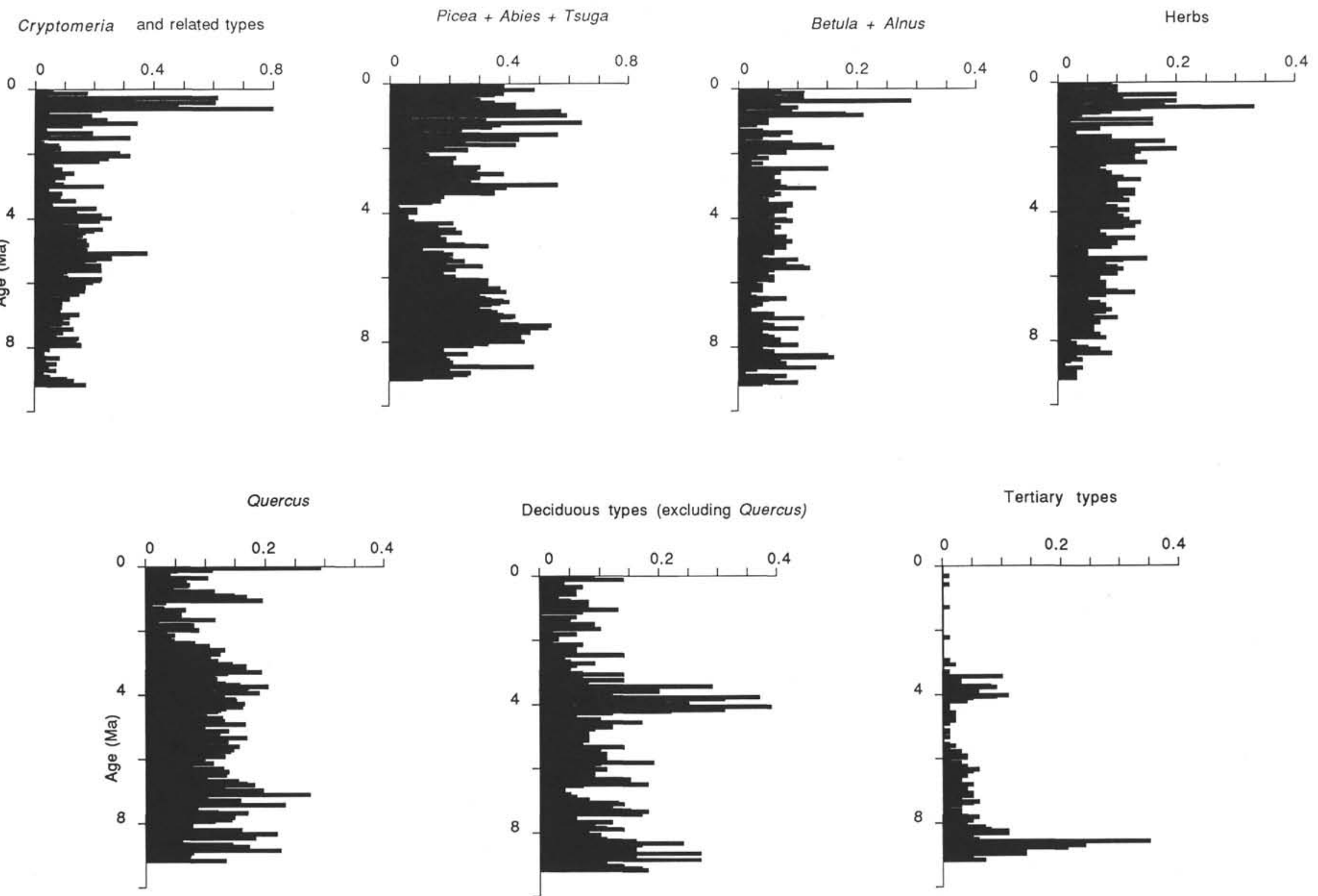

Deciduous types (excluding Quercus)

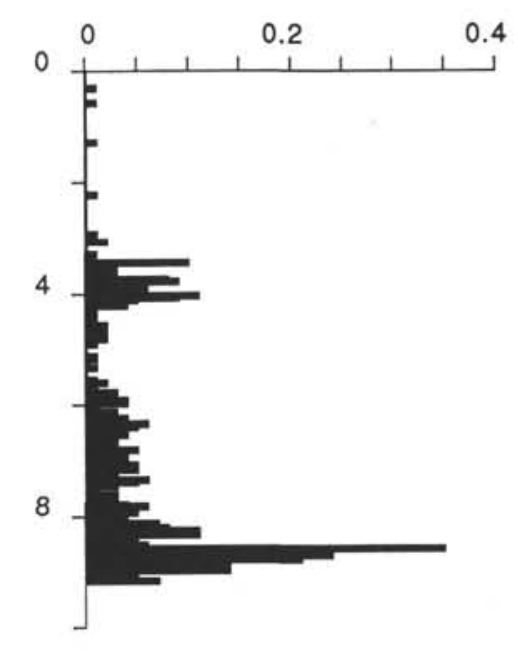

Figure 3. Percentages of selected pollen taxa from Hole 794A plotted to age.

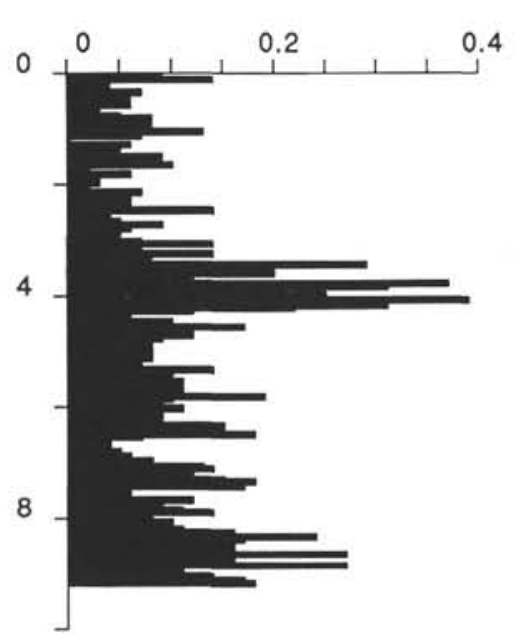


Concentration (X100)

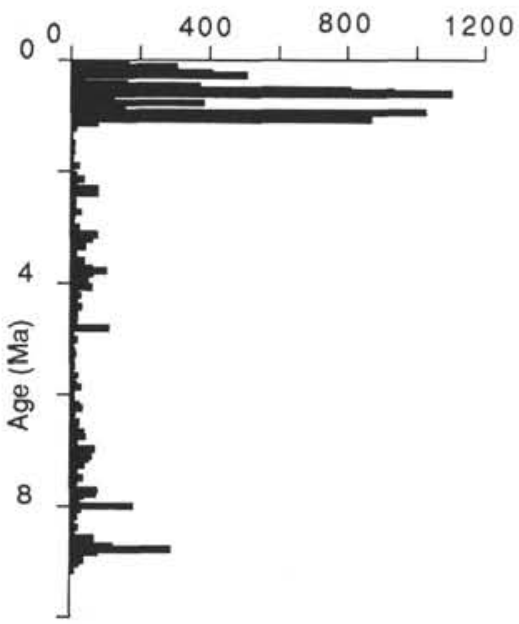

Picea + Tsuga + Abies

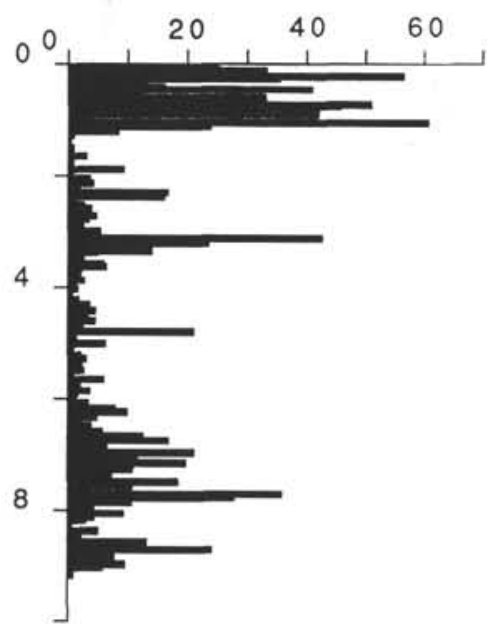

Deciduous types (excluding Quercus)

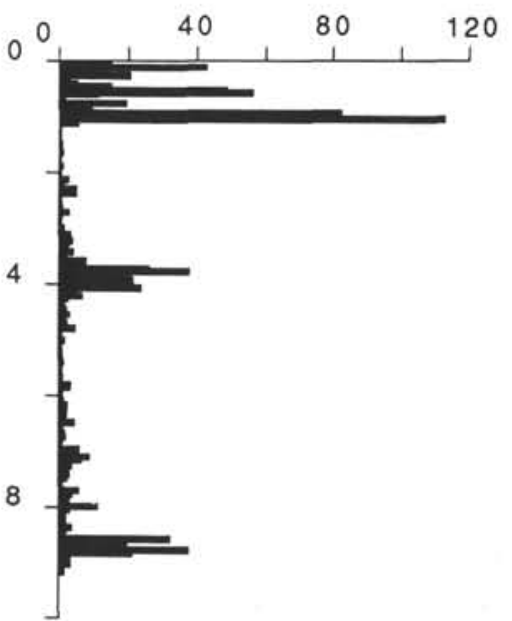

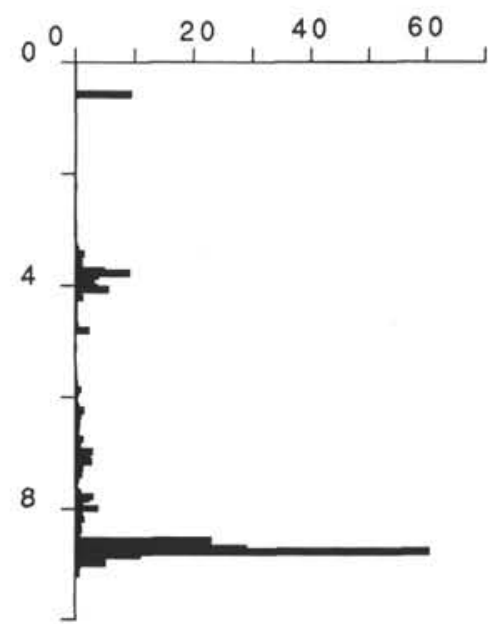

Figure 4. Concentration of pollen (pollen/gwds) from Hole 794A plotted to age. 

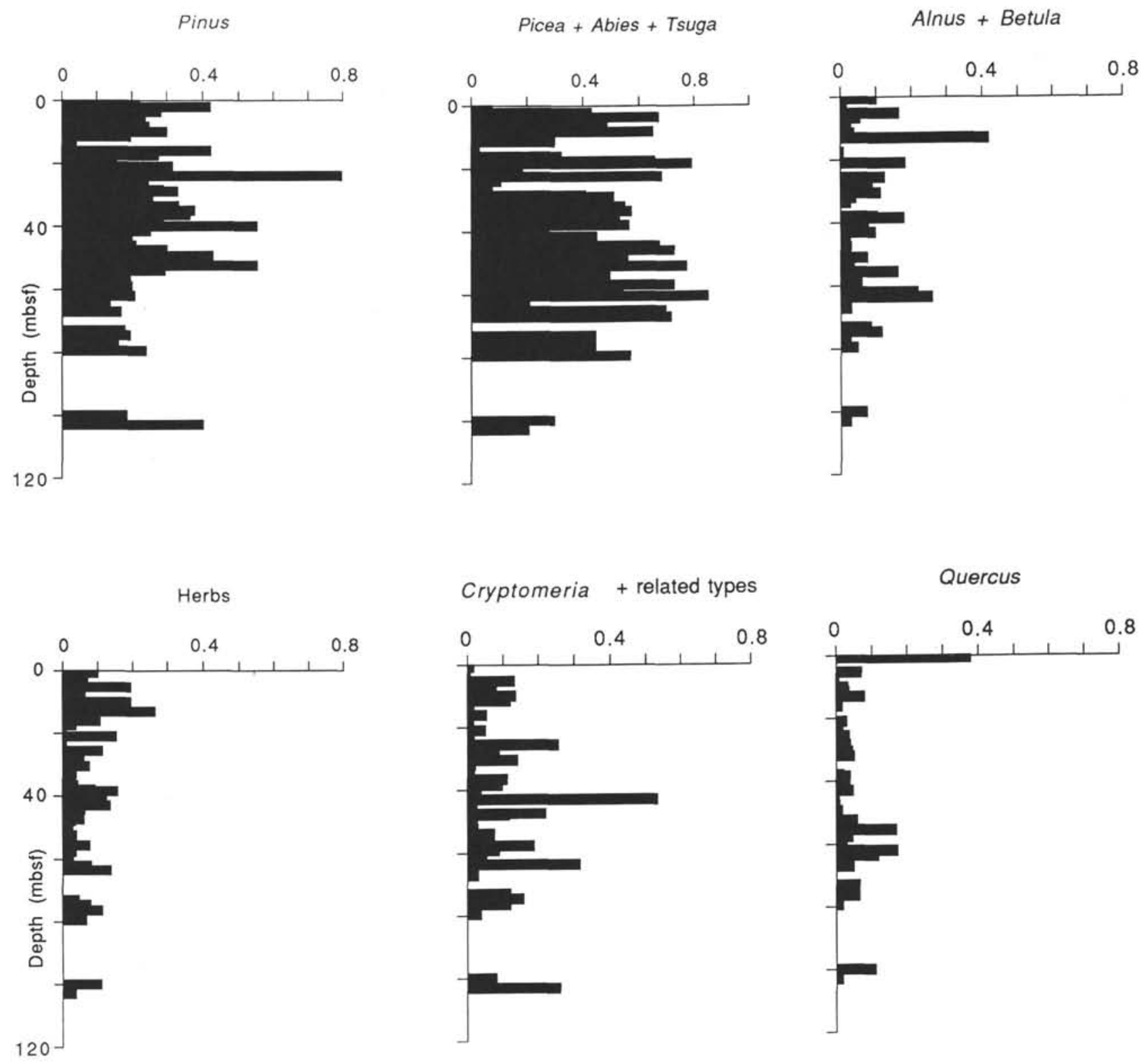

Figure 5. Percentages of selected pollen taxa from Hole 795A plotted to depth.

productive middle Pliocene samples in Hole 797A and/or inadequate age control.

In samples $>7$ m.y., pollen was even less abundant and less well preserved than in younger sediments from Hole 794A, although few of the samples analyzed were totally barren. It is interesting to note that in the three middle Miocene samples that had $>100$ pollen grains, percentages of the Picea + Tsuga + Abies group are generally high and percentages of Pinus are strikingly low. Tertiary types contribute about equally with Quercus and other deciduous pollen, and Betula + Alnus and herbs are less important (Figs. 8 and 9).

\section{SUMMARY}

\section{Evaluation of Pollen in Holes 794A, 795A, and 797B}

The concentration of pollen in Neogene sediments from Holes 794A, $795 \mathrm{~A}$, and 797B in the Sea of Japan is high, comparable to pollen concentration in Japanese bogs (Tsukada, 1967) and exceeding that reported from piston cores and ODP cores in the Arabian Sea and the North Pacific and Atlantic oceans (Heusser, 1977; Van Campo, 1986; Dupont, 1989). The highest pollen concentrations in samples from these three Japan Sea sites are similar to those from Site 565 in the equatorial eastern Pacific, which is very close $(\sim 42 \mathrm{~km})$ to land (Horn, 1985). Although the taxonomic diversity of the marine pollen assemblages in the Sea of Japan sediments is generally not as large as the diversity of taxa reported from nearby terrestrial sites (Tsukada, 1988; Miyoshi, 1989), the presence of pollen from the diagnostic taxa of vegetation/climate zones in these marine sediments provides a means of reconstructing a broad picture of changes in the vegetation and environments near the Sea of Japan throughout the Neogene.

\section{Source of Pollen in Samples from Sites 794, 795, and 797}

By marine standards, Sites 794, 795, and 797 lie close to land; viewed from land, the core sites, which are located between $\sim 100 \mathrm{~km}$ 

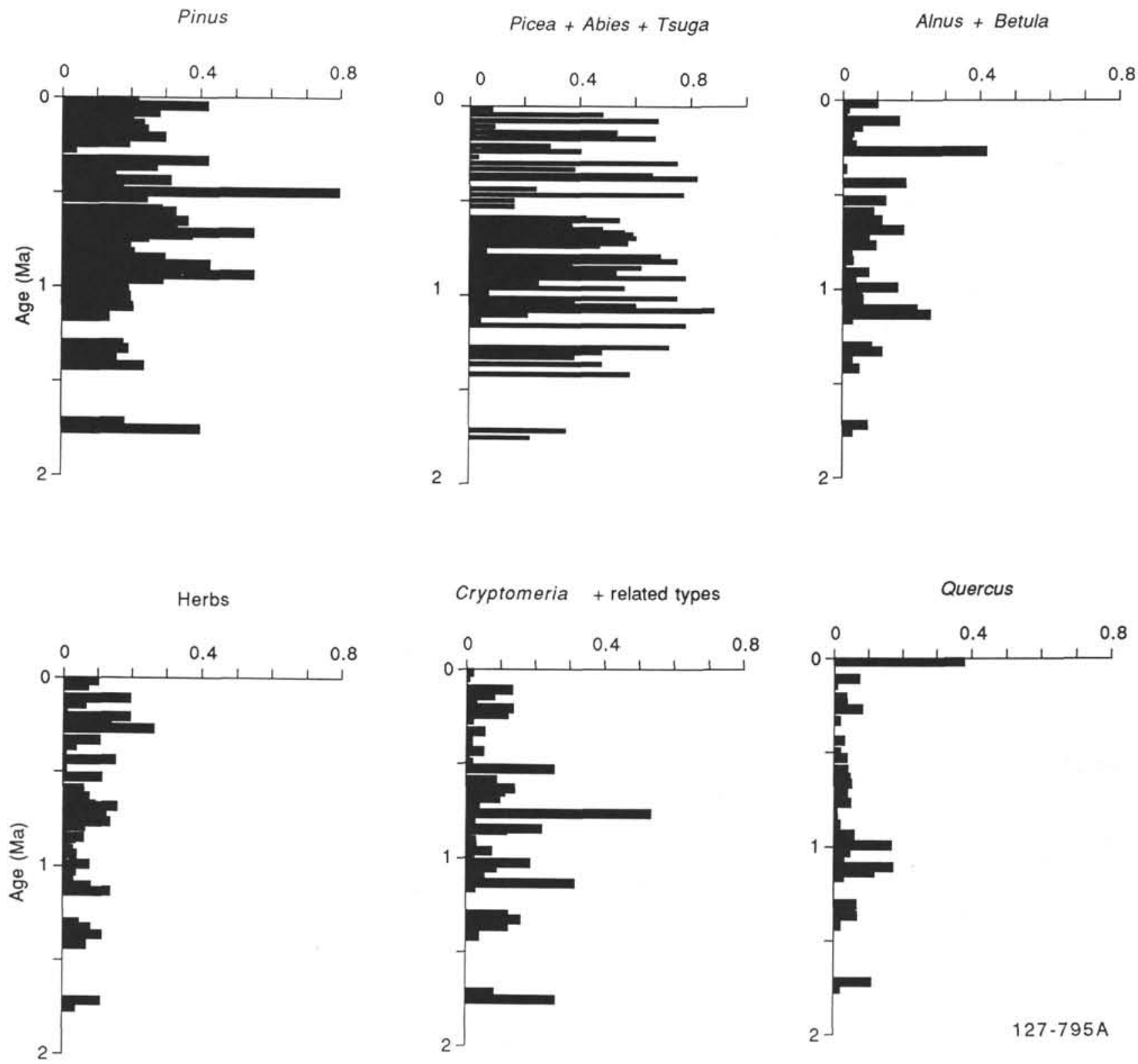

Figure 6. Percentages of selected pollen taxa from Hole 795A plotted to age.

and $\sim 300 \mathrm{~km}$ offshore, lie far beyond the limits of local pollen dispersal and deposition. Theoretical and empirical evidence has shown that the quantity of pollen transported long distances by wind is minuscule compared with the quantities produced and deposited locally, i.e., within a few meters of the plant source (Raynor et al., 1972; Traverse, 1988). Although local orographic winds and the prevailing westerlies, which blow southeast in the summer and northeast in the winter, may carry some pollen offshore, rivers are probably the major factor in transporting pollen to the Sea of Japan, as in other temperate environments (Akers et al., 1979; Heusser, 1988, 1989; Traverse, 1988). Greatest fluvial pollen transport now probably occurs in spring (the time of winter snowmelt and the Bai-u rains), when maximum arboreal pollen production in Japan corresponds to maximum river discharge (Fukui, 1977; Igarashi, 1979, 1987; Heusser, 1988). The major point-source for pollen-bearing sediment in the Yamato Basin is the Toyama Channel (Tamaki, Pisciotto, Allan, et al.,
1990), which drains the region with highest precipitation in Japan (Fukui, 1977).

Comparison of recent marine core-top samples from the Sea of Japan and northeast Asian vegetation indicates that the primary source of pollen in the Yamato Basin is the vegetation of Japan (Morley and Heusser, 1989; Sarro, 1991). In sediments from Hole 795A, located midway between Hokkaido and Sikhote Alin, pollen derives from vegetation of both northern Japan and coastal Siberia. Primary sources of pollen in Neogene sediments from Sites 794, 795, and 797 presumably have not changed substantially in the last 2 m.y., since the uplift of eastern Honshu (Tamaki, Pisciotto, Allan, et al., 1990). Prior to this, tectonism must have affected the biogeography of both source regions and depositional environments (Ingle, Suyehiro, von Breymann, et al., 1990; Tamaki, Pisciotto, Allan, et al., 1990). In modern and Neogene marine sediments, clearly identifiable evidence of allochthonous pollen transport is minimal-the presence of rare 
Concentration $(\times 100)$

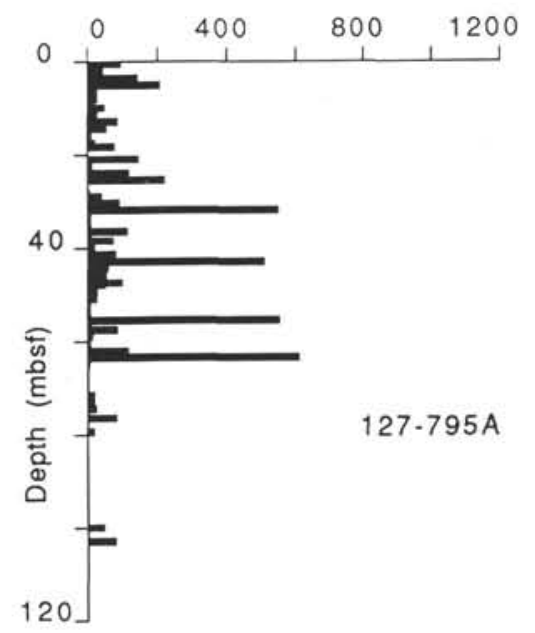

Concentration $(x 100)$

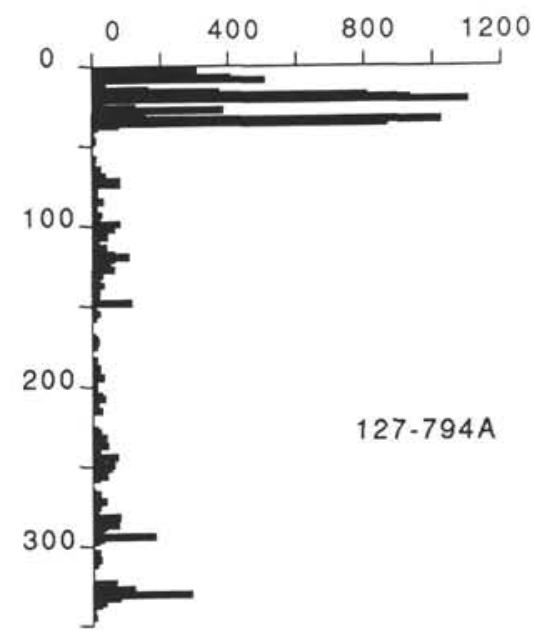

Figure 7. Concentration of pollen (pollen/gwds) from Holes 795A and 794A plotted to depth.

grains of Ephedra from the interior of China and possible northward transport of Cyptomeria.

\section{Neogene Environments Inferred from Pollen in Holes $794 \mathrm{~A}, 785 \mathrm{~A}$, and 797B}

\section{Vegetation}

Pollen data from Hole 794A are the primary source of this paleoenvironmental reconstruction of the last 9 m.y., not only because of the central location of Site 794 but also because of the length, continuity, and detail of the pollen record from this site (Figs. 2 and 3 ). Older Miocene vegetation (represented only by two samples from Hole 797B, Figs. 8 and 9), a mix of conifer and broad-leaf elements with Tertiary types well represented, appears comparable with late Miocene assemblages with very low quantities of Cryptomeria/Taxodiaceous types (presumably Metasequoia). Correlation with the middle Miocene Aniai flora of Japan is suggested by the relative abundance of coniferous components and by the presence of Carya, Liquidambar, and Nyssa (Huzioka, 1949, 1964; Shimada, 1967; Matsuo, 1972; Huzioka and Uemora, 1979).

In the late Miocene, the role of Tertiary types in the forests declines logarithmically, beginning at $\sim 9$ m.y. (Figs. 3 and 4 ). Conifers, including the Metasequoia/Sequoia/Cryptomeria/Taxodiaceae complex, became more prominent than broad-leaf elements at $\sim 8$ m.y. Following this initial prominence, the Picea complex decreased through the late Miocene. Herbs played an increased role in late Miocene vegetation, suggesting that forests were more open or that areas occupied by herbaceous vegetation became more plentiful. These broad trends in representation of forest components are composed of a complex mix of both high- and low- frequency changes that may reflect changing ecologic parameters, development of new ecological niches, as well as latitudinal or altitudinal variations in Japanese vegetation formations. The latter is suggested by the occasional presence of Selaginella selaginoides, a representative of snowbed vegetation, in Miocene samples from Hole 794A. Latitudinal vegetational variation on Japan is seen in the difference between the relative amounts of Cryptomeria and Tertiary types at Sites 794 and 797 (Figs. 3 and 9) and in the contrast between the warm and temperate forests with Tertiary elements of central Japan reconstructed from late Miocene pollen assemblages from Site 794 and the cold-temperate/boreal conifer-dominated late Miocene slope forests in northern Japan reconstructed from pollen in the Honbetsu Formation of Hokkaido (Igarashi et al., 1988).
On the north coast of the Sea of Japan, the late Miocene to early Pliocene transition was a low point for Tertiary elements in forests (Figs. 3, 4, and 9). Pollen abundance is low in sediments at Site 794 , possibly reflecting decreased production. In central Japan, Cryptomeria types (including grains tentatively identified as Metasequoia/Sequoia) were relatively more important and coldtemperate elements (the Picea group) were less important. In southwestern Japan, the role of these two groups was apparently reversed.

Middle Pliocene pollen assemblages from Hole 794A imply significant changes in forest development on western Japan. In the half-million-year interval centered at $\sim 4$ m.y., Tertiary and warmtemperate deciduous types reexpanded and were comparable to Tertiary types or greater than deciduous types at middle to late Miocene levels (Figs. 3, 4, and 9). Temperate and cold-temperate conifers (Picea + Abies + Tsuga $)$ were minimal throughout much of this time. Similar changes in central Honshu, a reexpansion of mixed forest with Tertiary-type conifers and broad-leafed trees (inferred from the Metasequoia pollen zone of the Pliocene-Pleistocene Osaka Group, and the development of warm-temperate Pinus trifolia vegetation; Miki, 1941; Tai, 1973) may be correlative; however, the chronology of these "Pliocene-Pleistocene" floras is not firmly established. It is possible that the warm-temperate Pliocene vegetation on Hokkaido, inferred from pollen assemblages that lie just below the Gilbert/Gauss boundary (Igarashi et al., 1989) may also correspond to the middle Pliocene event seen at Site 794. The apparent absence of this event in the preliminary pollen data from Hole 797B may indicate relative forest stability on southwestern Honshu or, as previously suggested, may reflect low sample resolution.

After $\sim 4$ m.y., basic themes which began in the late Miocene, modulated by high-frequency variations, continue. In late Pliocene forests, the decreased role of Tertiary and deciduous types is accompanied by a decrease in Quercus and Cryptomeria/Taxodiaceae types. Picea + Tsuga + Abies are again prominent and herbs continue to play a larger role in the vegetation of the main island of Japan (Figs. 2-4). Comparable trends occur on the northern island of Hokkaido, where Taxodiaceae decrease and Picea increases (Igarashi et al., 1988; Yahata et al., 1989). Between $\sim 3$ and $\sim 2.5$ m.y., conifers, except for Cryptomeria types, maintain their previous high profiles. In these late Pliocene forests, Quercus was diminishing and other broad-leaf trees were minimal. Forests of the next 0.5 m.y. contained even fewer broad-leaf representatives and Picea + Tsuga + Abies, more Cryptomeria and Pinus, and abundant herbs. Over the next 2 m.y., the very large and frequent changes in forest composition reconstructed from 


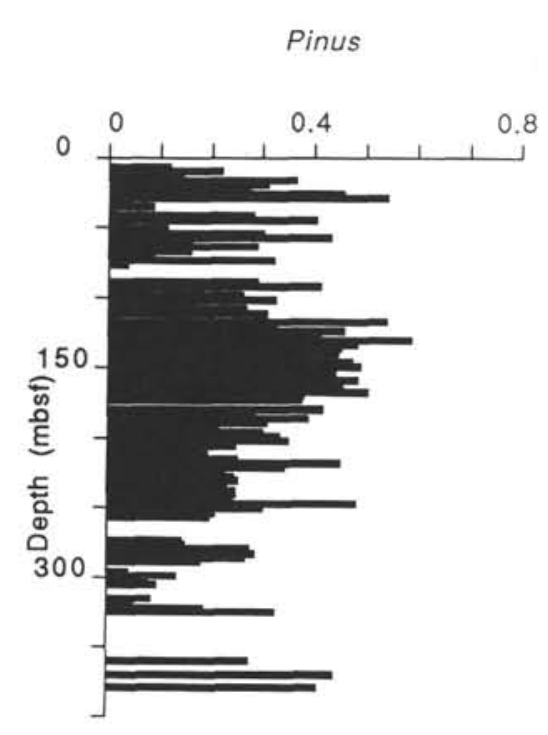

Picea + Tsuga + Abies
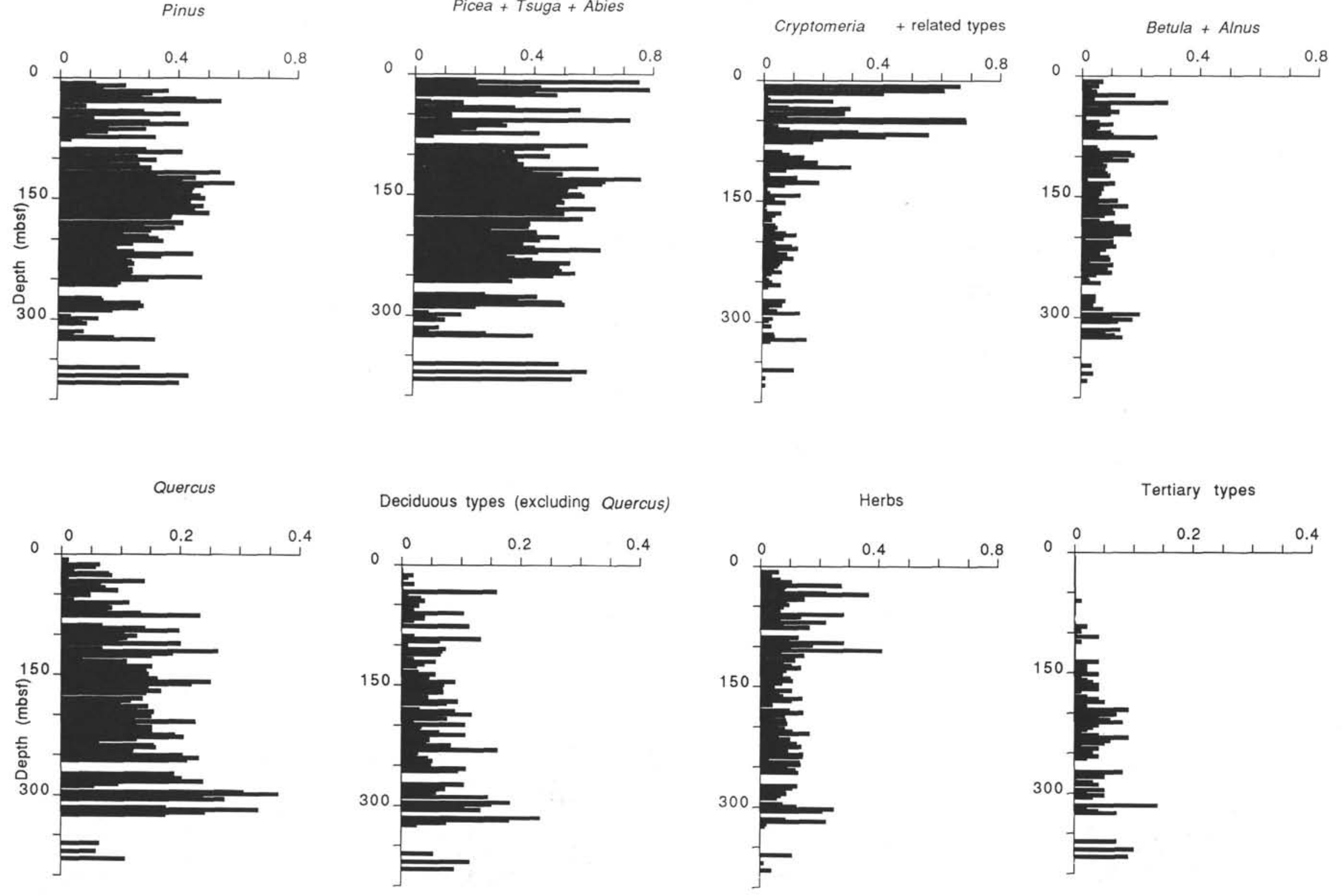

Figure 8. Percentages of selected pollen taxa from 797B plotted to depth. (Note variations in percentage scale.) 

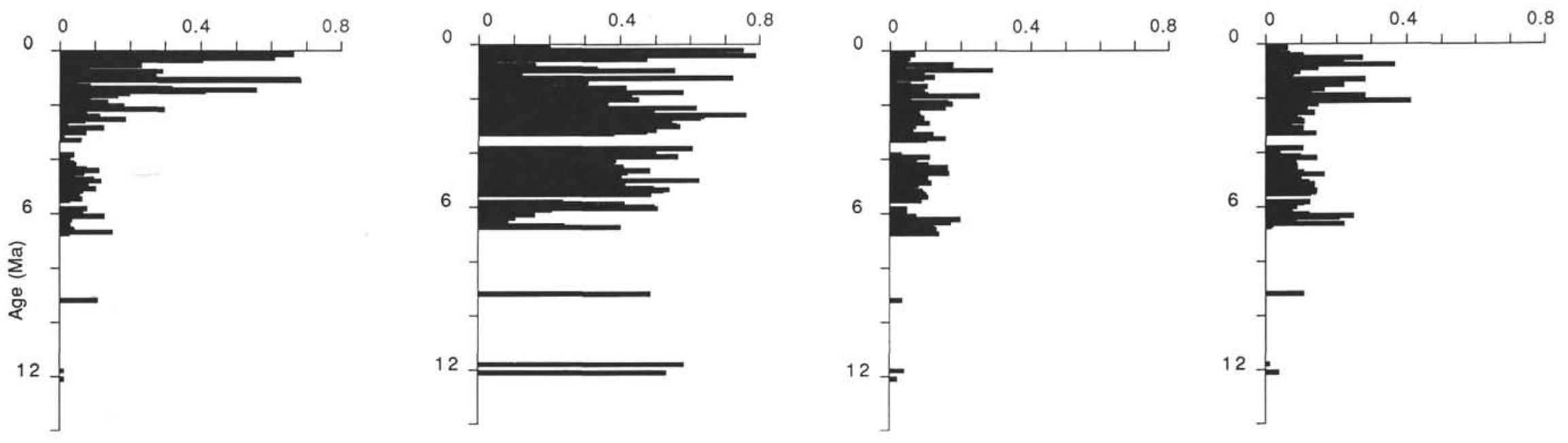

Quercus

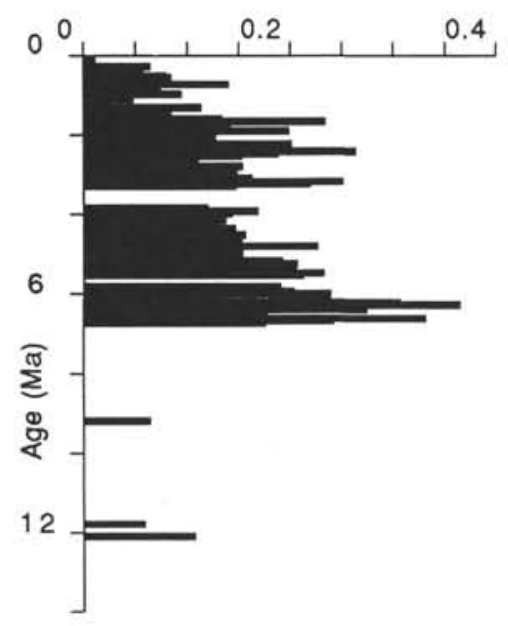

Deciduous types (excluding Quercus)

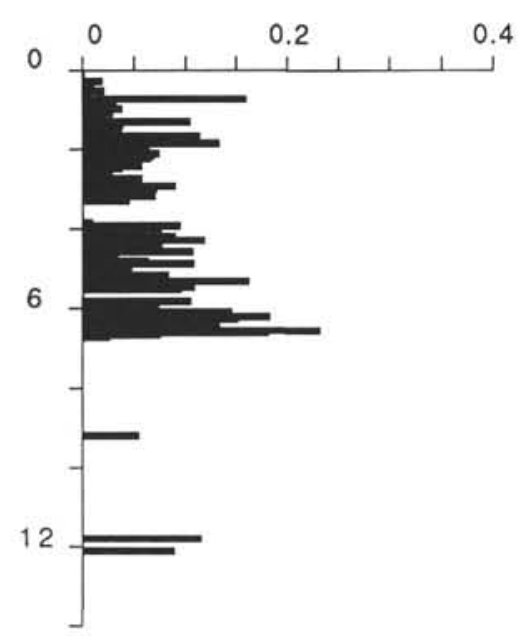

Tertiary types

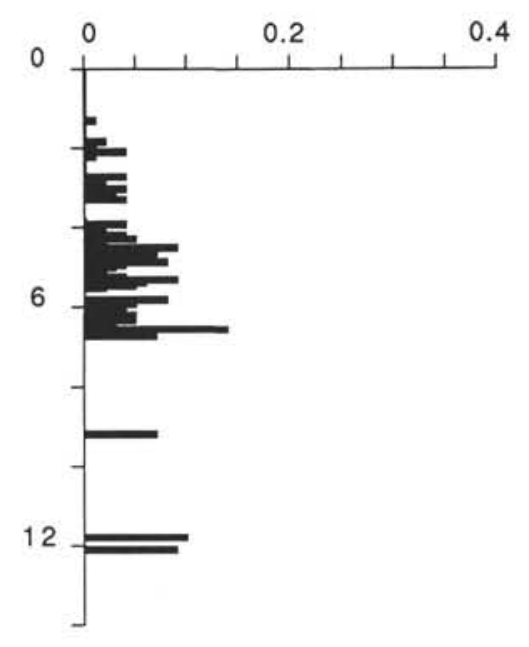

Figure 9. Relative amounts of selected pollen taxa in samples from Hole 797B plotted to age. 
pollen assemblages from Holes 794A, 795A, and 797B (Figs. 3-5 and 8 ) correspond to forest dynamics inferred from changes in pollen and floral assemblages throughout Japan (Tai, 1973; Igarashi, 1976; Hase and Hatanaka, 1984; Igarashi et al., 1988; Hayashida and Yokoyama, 1989; Yahata et al., 1989; Momohara et al., 1990).

\section{Inferred Neogene Climate}

This reconstruction of the Neogene climate from pollen data from Leg 127 in the Sea of Japan is based on the simplistic assumptions that (1) the vegetation of Japan is the principal source of pollen in sediments from the eastern Sea of Japan, (2) Neogene vegetation/climatic relationships were similar to those between present regional climatic parameters and modern Japanese vegetation, and (3) climate is a primary factor in Neogene vegetational change. It is recognized that these assumptions gloss over complicating factors such as the contribution of pollen from Sikhote Alin to Site 795, changes in vegetation/climate relationships over time (including the effect of disturbance of "natural potential" vegetation in Japan), possible evolution of plant taxa, and the significant role of volcanism on Japanese vegetation.

The most commonly occurring taxa used in northeast Asian paleoclimatic reconstructions are those illustrated in Figures 2-9. Taxodiaceous genera-particularly Cryptomeria, Sequoia, and Metasequoia - are used as warm, humid environmental indicators. In Japan, the abundance of Cryptomeria pollen is strongly correlated with high precipitation and is usually interpreted as indicative of moist, temperate and warm-temperate conditions (Tsukada, 1982, 1986). In the warm, moist mixed mesophytic forest of southeast China, Cryptomeria grows with Metasequoia, Liquidambar, Nyssa, and other trees that are part of the subtropical/warm-temperate forest associations of southern Japan (Wang, 1961). Other taxodiaceous types, such as Chamaecyparis and Thujopsis, are centered in the moist part of temperate zone in southwest Japan (Tsukada, 1988). All of these warm-temperate conifers are also associated with a long growing season, which allows them to out-compete deciduous angiosperms, as in the Pacific Coastal Forest of northwest North America.

Picea + Tsuga + Abies are commonly used as temperature indicators. Picea + Tsuga + Abies forests characterize the subalpine zones of Central Japan and the temperate zone of southwestern Japan (Tsukada, 1988). Picea and Tsuga pollen, particularly, are regarded as good indicators of subalpine/temperate environments in fossil sediments because the pollen is not found if the trees are not present in forests (Tsukada, 1988). Picea is associated with low winter temperatures and wet soil/poor drainage. Quercus is generally interpreted as indicative of precipitation and temperatures of warm temperate and mixed deciduous forest. Like that of Picea, Tsuga, and Cryptomeria pollen, Quercus pollen frequencies are highly correlated with vegetational abundance. Alnus and Betula, taxa important in succession, are associated with relatively low $\left(<8^{\circ} \mathrm{C}\right)$ mean annual temperatures (Jimbo, 1964; Tsukada, 1983, 1988). Interpreting the role of Pinus is more complex. Widely distributed in Japan today, Pinus is found in successional and stable habitats that range from subalpine to sea level, from the coasts of southern to northern Japan. Distribution of Pinus is closely associated with low effective soil moisture, and modern Pinus pollen frequency is high in warm- and mid-temperate zones (Tsukada, 1988). Herb/forb abundance is indicative of open environments, often cold or dry, or saline (Chenopodiaceae).

Using these vegetation/climate relationships as guides, the major features of the Neogene climate inferred from the preliminary pollen data from Holes 794A, 797B, and 795A are decreasing temperatures, increasing seasonality in temperatures and precipitation, and increasing amplitude and frequency of climatic change. Two brief peaks, centered at $\sim 9$ and $\sim 4$ m.y., punctuate the gradual deterioration of the equable warm, humid subtropical/warm-temperate late Miocene and early Pliocene climates. Following the middle Pliocene warm humid interval (Figs. 2-4), a rapid change to cooler drier late Pliocene environments began. In the pollen record from Hole 794A, the first indication of cold-temperate conditions comparable to those of Pleistocene glacial intervals occurs at $\sim 3$ m.y. Subsequently, regional Pleistocene temperate and cold-temperate climates oscillated rapidly between extremes of temperature and precipitation, which appear to have exceeded those of the earlier $7 \mathrm{~m} . \mathrm{y}$. The extremes, however, were never great enough to displace subtropical components of Japanese vegetation or to displace warm-temperate and temperate forests from Honshu. There is no evidence in any of the records of arctic climates off the west coast of Japan, which are climates similar to those that now prevail around the Sea of Okhotsk. On the west coast of Japan, temperate and cold-temperate climates, climates that support conifer and mixed broad-leaf forests, apparently prevailed through the late Pliocene and Quaternary, at least within the span of time represented in the samples analyzed from Holes 794A, 795A, and 797B.

\section{Implications of Paleoenvironmental Reconstructions}

The pollen data and inferred climatic changes imply that, over the time of record and within the time span of each sample, winter sea-surface temperatures off the southwest coast of Japan did not vary beyond the present extremes in the Sea of Japan for any extended interval. The pollen data also imply that even during Quaternary eustatic sea-level depressions, warm North Pacific waters must have modified the effects of the enhanced Siberian lows during winter. On the northwest coast of the western United States, unlike western Europe and northeastern United States, extremes of temperature and precipitation never exceeded present regional extremes for any extended interval during the Quaternary (Heusser, 1989, 1990; Morley and Heusser, 1989). As in the Japanese archipelago, the Quaternary climates of coastal Washington and Oregon were moderated by relatively warm offshore marine currents, even during glacial maxima.

\section{Comparison with Marine Paleoenvironmental Data from Sites 794, 795, and 797}

Overall, the paleoenvironmental implications of the preliminary pollen analyses from Sites 794, 795, and 797 in the Sea of Japan are readily correlated with broad changes in the marine environments of the Sea of Japan. For example, late Miocene cooling and Pleistocene high-frequency climate variations, the latter dramatically evidenced in the cyclic dark/light sediment cycles of the last million years, are reflected in both the terrestrial and marine records. In the last few million years of the Miocene, when warm humid terrestrial environments were rapidly shrinking, marine microfossils (diatoms, planktonic foraminifers, and calcareous nannofossils) indicate that surface waters at Site 794, 795, and 797 were cool (Tamaki, Pisciotto, Allan, et al., 1990). Upwelling during this time, suggested by the prominence of siliceous microfossils, may be corroborated by the rise in taxodiaceous pollen (Figs. 2-4), as in cores taken off coastal California (Sancetta et al., in press). Both early Pliocene marine and terrestrial environments are essentially similar to those of the late Miocene.

Like the pollen data, paleoceanographic data from Legs 127 and 128 give no evidence of complete isolation of the Sea of Japan from the Pacific (Ingle, Suyehiro, von Breymann, et al., 1990; Tamaki, Pisciotto, Allan, et al., 1990), although constriction of flow through the Tsushima Straits during glacial maxima is suggested. Unlike the pollen data, marine microfossil data in ODP cores do not reflect the middle Pliocene warming event, although it has been detected in detailed analyses of onshore Neogene sequences (e.g., Asamo et al., 1969). Conversely, the terrestrial microfossil records from the Sea of Japan do not suggest that late Pliocene cooling began at $\sim 2.4$ m.y., as do the marine microfossils (Tamaki, Pisciotto, Allan, et al., 1990). Late Pliocene cooling in Japan and northeast Asia (Gladenkov, 1988) appears to have begun after the $\sim 4-$ m.y. warm event ended and 
culminated between $\sim 3$ and $\sim 2.5$ m.y. The apparent differences between climatic reconstructions of marine and terrestrial environments in and around the Sea of Japan may reflect differing sensitivities and responses of these paleoenvironmental indicators; more likely, the differences reflect the comparison of discordant samples in these low-resolution preliminary studies.

\section{Comparison with Regional and Global Paleoenvironmental Data}

The Neogene paleoclimatic reconstruction derived from the analysis of pollen in Holes 794A, 7975A, and 797B resembles Neogene climatic reconstructions inferred from pollen and other Japanese and northeast Asian floral data (Tai, 1973; Gladenkov, 1988; Igarashi et al., 1988). Although this correlation is encouraging, close comparison at this time is necessarily precluded by the nature of differences in the data: that from land usually lacks continuous chronostratigraphic control, whereas the marine data are preliminary. Comparison of climatic changes inferred from the rather limited, initial pollen counts from the Sea of Japan with some climatic reconstructions from other parts of the world shows some interesting regional similarities and differences. Neogene aridification and cooling in Japan corresponds to uplift of the Tibetan Plateau (Ruddiman et al., 1989), a major factor in northeast Asian climate processes (Fukui, 1977). The 6-m.y. cooling inferred from pollen data in the Sea of Japan corresponds to the maximum expansion of Antarctic ice and increased aridity in Africa and Australia (Stein, 1986). Middle Pliocene warming, seen in the pollen data from Hole 794A, corresponds to the first of two middle Pliocene warming events, which began at $\sim 4$ m.y. in the North Atlantic (Dowsett and Poore, 1990); however, the 4-m.y. revival of "Tertiary type" climates on Japan coincides with increased cooling and aridification in the Southern Hemisphere and Northern Hemisphere inferred from oxygen isotope and lithologic analyses from Deep Sea Drilling Project Sites 141, 366, 397, and Hole 544B in the northeast Atlantic and DSDP Sites 588,590, and 591 in the southwest Pacific (Stein, 1986). Unlike Japan and the Sea of Japan, the northern subtropical and subpolar Pacific were warmer than present during the late Pliocene (2.7-3.0 m.y.) at a time when pollen data from Hole 794A and North Atlantic sea-surface temperatures imply that cooling was well under way (Sancetta and Silvestri, 1986; Dowsett and Poore, 1990; Morley and Dworetzky, 1991). The subsequent decrease in North Pacific surface temperatures at $\sim 2.5-2.4$ m.y., which corresponds to a late Pliocene initiation of Northern Hemisphere glaciation, is not reflected in the preliminary pollen records from Hole 794A.

\section{REFERENCES}

Akers, T., Edmonds, R., Kramer, C., Lighthart, B., McManus, M., Schlichting, H., Solomon, A., and Spendlove, J., 1979. Sources and characteristics of airborne material. In Edmonds, R. L. (Ed.), Aerobiology: Stroudsburg, PA (Dowden, Hutchison \& Ross), 41-55.

Asamo, K., Ingle, J. C., Jr., and Takayamaga, Y., 1969. Neogene planktonic foraminiferal sequence in northeastern Japan. In Brönnimann, P., and Renz, H. (Eds.), Proc. Ist Internat. Conf. Planktonic Microfossils. Leiden (E. J. Brill), 1:14-25

Dowsett, H. J., and Poore, R. Z., 1990. A new planktic foraminifer transfer function for estimating Pliocene-Holocene paleoceanographic conditions in the North Atlantic. Mar. Micropaleontol., 16:1-23.

Dupont, L. M., Beug, H.-J., Stalling, H., and Tiedemann, R., 1989. First palynological results from Site 658 at $21^{\circ} \mathrm{N}$ off northest Africa: pollen as climate indicators. In Ruddiman, W., Sarnthein, M., et al., Proc. ODP, Sci. Results, 108: College Station, TX (Ocean Drilling Program), 93-111.

Franklin, J. F., Maeda, T., Ohsumi, Y., Matsui, M., and Yagi, H., 1979. Subalpine coniferous forests of central Honshu, Japan. Ecol. Mono., 49:311-354.

Fuji, N.. 1988. Palaeovegetation and palaeoclimate changes around Lake Biwa, Japan during the last ca. 3 million years. Quat. Sci. Rev., 7:21-28.

Fukui, E., 1977. The Climate of Japan: New York (Elsevier).
Gladenkov, Y. B., 1988. The North Pacific Holarctic Neogene from an ecostratigraphic point of view. In Prof. T. Kotaka Commemorative Volume: Saito-Ho-on Kai Spec. Publ., 33-45.

Hase, Y., and Hatanaka, K., 1984. Pollen stratigraphical study of the Late Cenozoic sediments in southern Kyushu, Japan. Quat. Res. Jpn., 22:1-20.

Hayashida, A., and Yokoyama, T., 1989. Brunhes/Matuyama polarity epoch boundary in the Osaka Group of the Senriyama Hills, southwest Japan. Palaeogeogr., Palaeoclimatol., Palaeoecol., 72:195-201.

Heusser, L., 1977. Pollen distribution in the northeast Pacific Ocean. Quat. Res., 7:45-62.

1988. Pollen distribution in marine sediments on the continental margin off Northern California. Mar. Geol., 80:131-147.

-1989. Northeast Asian climatic change over the last 140,000 years inferred from pollen in marine cores taken off the Pacific Coast of Japan. In Leinen, M., and Sarthein, M., (Eds.), Paleoclimatology and Paleometeorology: Modern and Past Patterns of Global Atmospheric Transport: Dordrecht (Kluwer), 665-692.

1990. Northeast Asian pollen records for the last 150,000 years from deep-sea cores V28-304 and RC14-99 taken off the Pacific coast of Japan. Rev. Palaeobot. Palynol., 65:1-8.

Heusser, L., and Stock, C., 1984. Preparation techniques for concentrating pollen from marine sediments and other sediments with low pollen density. Palynology, 8:225-227.

Horn, S. P., 1985. Preliminary pollen analysis of Quaternary sediments from Deep Sea Drilling Project Site 565, western Costa Rica. In von Huene, R. Aubouin, J., et al., Init. Repts. DSDP, Washington (U.S. Govt. Printing Office), 533-547.

Huzioka, K., 1949. Two Daijima floral types in the inner zones of northeastern Japan. Geol. Soc. Jpn., 55:69-86.

, 1964. The Aniai flora of Akita Prefecture and the Aniai-type floras in Honshu. J. Akita Univ. Mining Coll., 3:1-105.

Huzioka, K., and Uemora, K., 1979. The Comptonia-Liquidambar forest during the Middle Miocene Daijima age in Japan. Rept. Akita Univ. Mining Coll. Res. Inst. Undergr. Resour., 45:37-52.

Igarashi, T., 1986. Forest vegetation of the Akan National Park, Hokkaido, Japan. Res. Bull. Coll. Exptl. For., Hokkaido Univ., 43:335-494

Igarashi, Y., 1976. The first cold phase during Plio-Pleistocene time in Hokkaido. J. Geol. Soc. Jpn., 82:357-344.

1979. Pollen incidence and wind transport in central Hokkaido (1). J. Fac. Sci. Hokkaido Univ., 19:257-264.

, 1987. Pollen incidence and wind transport in central Hokkaido (2) Res. Bull. Coll. Exp. For. Fac. Agri. Hokkaido Univ., 44:477-506.

Igarashi, Y., Tonosaki, T., and Yoshida, M., 1988. Pollen stratigraphy of the Honbetsu and Ashoro formation, Tokachi Group. Earth Sci. (Jpn.), $42: 277-289$

Ingle, J. C., Jr., Suyehiro, K., von Breymann, M. T., et al., 1990. Proc. $O D P$, Init. Repts., 128: College Station, Texas (Ocean Drilling Program).

Ishii, J., Igarashi, Y., Sasaki, S., Mino, N., and Matsumoto, K., 1981. On the peats collected from the continental shelf of the Isikari Bay, Hokkaido, Japan. Earth Sci., 35:231-239.

Jimbo, T., 1964. The pollen flora of Japan since Pliocene time and its macrobotanical background. Sci. Rep. Tohoku Imperial Univ., 7:129-132.

Koroneva, E. V., 1961. Investigation by method of pollen and spore analysis of two marine cores from the Sea of Japan. Oceanogr. T. Geol. Inst. Academy Sci. USSR, 126:1-16.

Maeda, Y., 1970. Palynological study of the Latest Pleistocene marine clay in the Itami area, Kinki, Japan. J. Geosci. Osaka City Univ., 13:99-112.

Matsuo, H., 1972. A study of the so-called "Daijima-type" floras from Fukui, Ishikawa and Toyama Prefectures, inner side of Japan.Ann. Sci. Kanazawa Univ., 9:81-98. (in Japanese)

Miki, S., 1941. On the change of flora in eastern Asia since the Tertiary Period. Jpn. J. Bot., 11:237-303.

Miyoshi, N., 1984. Pollen morphology by means of scanning electron microscope. 9. Caryophyllales (Angiospermae). Bull. Hiruren Res. Inst. Okayama Univ. Sci., 10:45-58.

- 1986. Pollen morphology by means of scanning electron microscope 10. Polygonales (Angiospermae). Bull. Hiruren Res. Inst., Okayama Univ. Sci., 12:19-33.

, 1989. Preliminary pollen analytical study of a late-Pleistocene deposit from Tokusa Basin, Yamaguchi Prefecture. Quat. Res. Jpn., 28:41-48.

Momohara, A., Mizuno, K., Tsuji, A., and Kokawa, S., 1990. Early Pleistocene plant biostratigraphy of the Shobudani Formation, southwest Japan, with reference to extinction of plants. Quat. Res. Jpn., 29:1-19. 
Morley, J., and Dworetzky, B. A., 1991. Evolving Plio-Pleistocene climate: a North Pacific perspective. Quat. Sci. Rev., 10:225-238.

Morley, J., and Heusser, L., 1989. Late Quaternary atmospheric and oceanographic variations in the western Pacific inferred from pollen and radiolarian analysis. Quat. Sci. Rev., 8:263-276.

Morley, J., Heusser, L., and Sarro, T., 1986. Latest Pleistocene and Holocene palaeoenvironment of Japan and its marginal sea. Palaeogeogr., Palaeoclimatol., Palaeoecol., 53:349-358.

Numata, M., 1974. The Flora and Vegetation of Japan: New York (Elsevier).

Ohwi, J., 1984. Flora of Japan: Washington (Smithsonian Inst).

Raynor, G. S., Ogden, E. C., and Hayes, J. V., 1972. Dispersion and deposition of timothy pollen from experimental sources. Agri. Meteor., 9:347-366.

Ruddiman, W. F., Prell, W. L., and Raymo, M. E., 1989. Late Cenozoic uplift in southern Asia and the American West: rationale for general circulation modeling experiments. J. Geophys. Res., 94:18379-18391.

Saito, K., 1979. A note on subalpine forests in north Honshu, Japan. Bull. Yokohama Phytosociol. Soc. Jpn., 16:177-188.

Sancetta, C., Heusser, L., Lyell, M., Zahn, R., and Bradbury, J. P., in press. Late-glacial to Holocene changes in upwelling and seasonal production of the northern California current system. Quat. Res.

Sancetta, C., and Silvestri, S. M., 1986. Pliocene-Pleistocene evolution of the North Pacific Ocean-atmosphere system, interpreted from fossil diatoms. Paleoceanography, 1:163-180.

Sarro, T., 1991. Quaternary Paleoecology of Japan: evidence from marine palynology [Ph.D. dissert.]. New York Univ., New York.

Shimada, M., 1967. The pollen flora from the Tertiary and Cretaceous of Japan in correlation with the paleobotanical records. Rev. Palaeobot. Palynol., $5: 235-241$.

Shipboard Scientific Party, 1990a. Sites 788/789. In Taylor, B., Fujioka, K., et al., Proc. ODP, Init. Repts., 126: College Station, TX (Ocean Drilling Program), 97-126.

, 1990b. Site 794. In Tamaki, K., Pisciotto, K., Allan, J., et al., Proc. ODP, Init. Repts., 127: College Station, TX (Ocean Drilling Program), 71-167.

, 1990c. Site 798. In Ingle, J. C., Jr., Suyehiro, K., von Breymann, M. T., et al., Proc. ODP, Init. Repts., 128: College Station, TX (Ocean Drilling Program), 121-236.
Stein, R., 1986. Late Neogene evolution of paleoclimate and paleoceanic circulation in the Northern and Southern Hemispheres-a comparison. Geol. Rundsch., 75:125-138.

Tai, A., 1973. A study of the pollen stratigraphy of the Osaka Group, PliocenePleistocene deposits in the Osaka Basin. Mem. Fac. Sci. Kyoto Univ., Ser. Geol. Mineral, 39:123-165.

Tamaki, K., Pisciotto, K., Allan, J., et al., 1990. Proc. ODP, Init. Repts., 127: College Station, TX (Ocean Drilling Program).

Traverse, A., 1988. Paleopalynology: Boston (Unwin Hyman).

Tsukada, M., 1967. Pollen succession, absolute pollen frequency and recurrence surfaces in central Japan. Am. J. Bot., 54:821-831.

, 1982. Cryptomeria japonica: glacial refugia and late-glacial and postglacial migration. Ecology, 6:1091-1105.

1983. Vegetation and climate during the last glacial maximum in Japan. Quat. Res., 19:212-235

, 1986. Altitudinal and latitudinal migration of Cryptomeria japonica for the past 20,000 years in Japan. Quat. Res., 26:135-152.

1988. Japan. In Huntley, B., and Webb, T., III (Eds.), Vegetation History: Dordrecht (Kluwer), 459-518.

Ueno, J., 1951. Morphology of pollen of Metasequoia, Sciadopitys, and Taiwania. J. Inst. Polytech. Osaka City Univ., 2:22-25.

Van Campo, E., 1986. Monsoon fluctuation in two 20,000-yr B.P. oxygenisotope pollen records off southwest India. Quat. Res., 26:376-388.

Wang, C.-W., 1961. The Forests of China: Cambridge (Harvard Univ. Press).

Watanabe, S., 1979. The subarctic summer green forest zone in northeastern Asia. Bull. Yokohama Phytosoc. Soc. Jpn., 16:101-111.

Yahata, M., Igarashi, Y., Gautam, P., and Wada, N., 1989. Plio-Pleistocene in the eastern part of Toya Lake, southwest Hokkaido: sedimentary facies, pollen stratigraphy and magnetostratigraphy. Earth Sci. (Jpn.), 43:261-276.

Date of initial receipt: 11 March 1991

Date of aceptance: 5 December 1991

Ms 127/128B-139 